\title{
Collection of Native Strawberry Germplasm in the Pacific Northwest and Northern Rocky Mountains of the United States
}

\author{
James J. Luby \\ Department of Horticultural Science, University of Minnesota, St. Paul, MN 55108 \\ James F. Hancock, Jr. \\ Department of Horticulture, Michigan State University, East Lansing, MI 48824 \\ James R. Ballington \\ Department of Horticultural Science, North Carolina State University, Raleigh, NC 27695
}

The cultivated strawberry (Fragaria $\mathrm{x}$ ananassa Duch.) is an interspecific hybrid complex derived from two octoploid $(2 \mathrm{n}=$ 56) species: F. chiloensis (L.) Duch., native to the Pacific coasts of North and South America, the southern Andes Mountains, and Hawaii; and $F$. virginiana Duch., found in North America from Alaska through the Sierra Nevada and Rocky Mountain ranges and throughout the eastern part of the continent (Darrow, 1966; Hancock et al,, 1990; Scott and Lawrence, 1975; Staudt, 1962). Outside of the western hemisphere and Hawaii, octoploid strawberries have been reported only on islands of the western Pacific Ocean. Frugaria iturupensis Staudt was described from the Kuril Islands, U.S.S.R. (Staudt, 1973), and an unassigned octoploid plant was collected from Rebun Island, Hokkaido Prefecture, Japan (Oda and Nisitani, 1989).

The evolution of strawberry at the octoploid level thus occurred largely in North America, making this continent an important source of wild germplasm. However, relatively few genotypes of $F$. virginiana have been used in developing the crop. The narrow germplasm base of North American strawberry production has recently been documented. Only 53 founding clones (Sjulin and Dale, 1987) representing 17 cytoplasm sources (Dale and Sjulin, 1990) are rep

Received for publication 21 Dec. 1990. Accented for publication 28 Aug. 1991. Minnesota Agr. Expt. Sta. Scientific Journal Series no. 18,659. These collections were funded by U.S. Dept. of Agriculture Plant Exploration funds. We are grateful for the cooperation of Harry Lagerstadt, Otto Jahn, Kim Hummer, and other personnel at the National Clonal Germplasm Repository Corvallis, Ore., who provided logistical support for these expeditions. We also appreciate the invaluable assistance of district resource officers of the National Forest Service and National Park Service and David Danley of Sun River Resort in locating suitable plant populations. Carl Rosen, Mark Strefeler, Todd Wehner, Amy Iezzoni, and Eric Hanson provided helpful reviews of the manuscript. The cost of publishing this paper was defrayed in part by the payment of page charges. Under postal regulations, this paper therefore must be hereby marked advertisement solely to indicate this fact. resented in the 134 North American cultivars introduced during the last 30 years. Furthermore, the 20 cultivars that account for most of the North American strawberry crop can be traced to 38 founding clones, of which just seven account for $\approx 50 \%$ of the genetic contribution (Galletta and Maas, 1990; Luby et al., 1991).

We collected Fragaria spp. in 1985 from 20 inland sites in the Pacific Northwest and, in 1989, from 53 sites in the northern Rocky Mountains (Fig. 1). The collection was made to obtain representatives of native Fragaria for maintenance at the U.S. Dept. of Agriculture (USDA) National Clonal Germplasm Repository (Corvallis, Ore.) and for distribution to-strawberry breeders and other researchers. Certain accessions may provide new sources of resistance to environmental and biotic stresses and improved fruit quality and productivity. Use of this material in breeding programs would broaden the strawberry germplasm base, reducing genetic vulnerability (Luby et al., 1991). The collections also provided material for specific ongoing research in Frugaria systematics, yield ef- ficiency and $\mathrm{C}$ exchange capacity, cold hardiness, disease resistance, and fruit quality.

The germplasm collected on these expeditions was deposited at the National Clonal Germplasm Repository in Corvallis, and limited quantities of accessions are available to researchers on request '(Curator, USDA National Clonal Germplasm Repository, Corvallis, OR 97333). An import permit may be necessary for foreign deliveries. USDA phytosanitary certificates are available upon receipt of the import permit.

\section{NATIVE STRAWBERRY GERMPLASM IN MONTANE WESTERN NORTH AMERICA}

The wild octoploid strawberries of montane western North America were referred to as two subspecies in the most recent taxonomic revision by Staudt (1962), F. virginiana ssp. glauca (Wats.) Staudt and ssp. platypetala (Rydb.) Staudt. Only six genotypes of western $F$. virginiana (identified as $F$. virginiana glauca) are represented among the 53 founding clones traced by Sjulin and

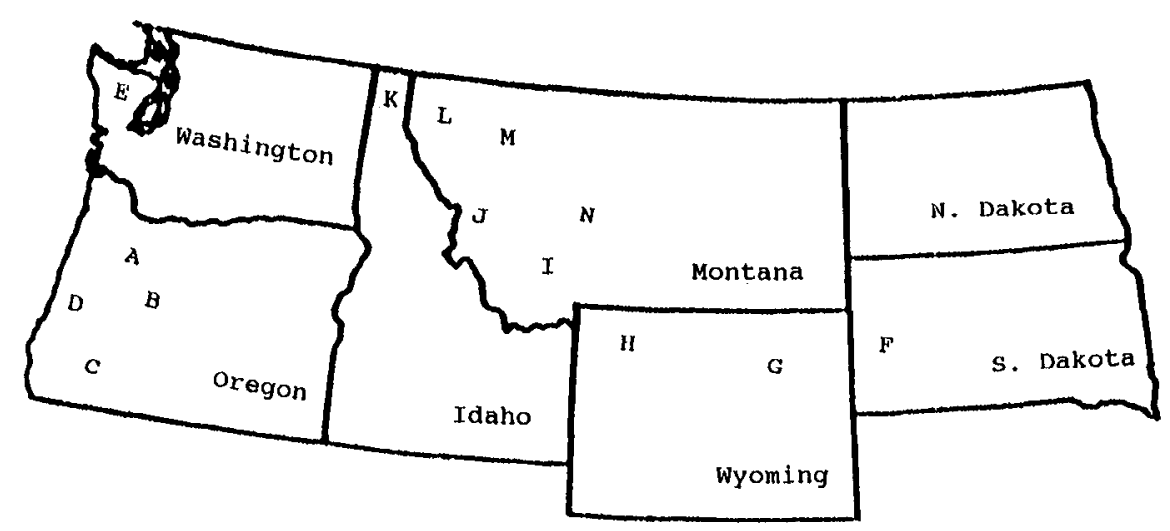

Fig. 1. Map of the western United States showing target regions for Fragaria germplasm collections in 1985 and 1989: A, Cascade Mountains (west slope); B, Cascade Mountains (east slope); C, Siskiyou Mountains; D, Coast Range; E, Olympic Mountains; F, Black Hills; G, Bighorn Mountains; H, Absoroka Range and Yellowstone Plateau; I, Madison, Tobacco Root, and Pioneer Mountains; J, Bitteroot Range; K, Cabinet and Selkirk Ranges; L, Flathead and Whitefish Ranges; M, Lewis Range; N, Big Belt, Little Belt, and Crazy Mountains. 
Dale (1987). However, the utility of $F$. virginiana ssp. glauca for improvement of several important traits in the cultivated strawberry has been well documented. Hildreth and Powers (1941) and Powers (1944, $1945,1954)$ observed that genotypes from the Rocky Mountains contributed considerable winter hardiness, tolerance of blossoms to frost, early maturity, and good fruit quality. Darrow (1966) indicated that it was also a potential source of drought tolerance and resistance to powdery mildew [ Sphaerotheca macularis (Tul.) Lindau], red-stele root rot (Phytophthora fragariae Hickman), and root knot nematode (Maloidogyne hapla Chitwood). Newton and Van Adrichem (1958) found that some genotypes were resistant to verticillium wilt (Verticillium albo-atrum Reinke and Berth). The important everbearing and day-neutral flowering characteristics were also derived from this species (Ahmadi et al., 1990; Bringhurst and Voth, 1984; Ourecky and Slate, 1968; Powers, 1954; Scott, 1959).

Hildreth and Powers (1941) collected and evaluated some 42,000 genotypes of $F$. virginiana ssp. glauca from 1100 sites in the Rocky Mountains in the 1930s and 1940s. While some of this germplasm was used in further breeding to produce cultivars (Darrow, 1966; Scott and Lawrence, 1975) still grown on a limited basis, this massive collection was lost with the closing of the USDA small fruit research program at Cheyenne, Wyo. More recently, $F$. virginiana ssp. glauca germplasm from two sites in the Sierrra Nevada in California was collected and evaluated by Hancock and Bringhurst (1979, 1988).

Fragaria vesca L., a diploid, is the only native North American strawberry in addition to the octoploids (Darrow, 1966; Scott and Lawrence, 1975; Staudt, 1962). It is also widespread in Europe and Asia. All other diploid, tetraploid, and hexaploid species occur only in Asia and Europe (Darrow, 1966).

Little is known about the potential germplasm value of Pacific Northwest or Rocky Mountain populations of $F$. vesca, but data from other montane populations suggest they may possess useful genetic variability. Collections from high elevations in California had cold tolerance and earliness, and produced a high flowers : runners ratio (Hancock, 1977; Hancock and Bringhurst, 1978). This germplasm also was frost resistant and had reduced susceptibility to root rot. One population from Hecker Pass, Calif., had an unusually high reproductive effort in terms of flowers per plant and mean fruit weight (Hancock and Bringhurst, 1988). Genes for these traits could be transferred to octoploids through synthetic polyploids (Bringhurst and Voth, 1984).

\section{COLLECTION EXPEDITIONS}

A primary objective of the expeditions was to collect seeds, clones, and herbarium specimens of $F$. virginiana and $F$. vesca. Material of other local native fruit species (Rubus, Vaccinium, Ribes, Vitis, Prunus, Malus,
Sorbus, and Sambucus) was also collected where available and as time permitted (Ballington et al., 1988; Luby and Hancock, 1991). In 1985, collections were made between 21 July and 13 Aug. The Coast Range of Oregon, the Siskiyou Mountains (Oregon), the southern Cascade Mountains (Oregon and Washington), and the Olympic Mountains (Washington) were the target areas for the 1985 expedition (Fig. 1). In 1989, collections were made between 31 July and 19 Aug. The Black Hills (South Dakota), and the Bighorn (Wyoming), Absoroka (Wyoming and Montana), Madison (Montana), Tobacco Root (Montana), Pioneer (Montana), Bitteroot (Montana and Idaho), Selkirk (Idaho), Cabinet (Montana), Whitefish (Montana), Crazy (Montana), Big Belt (Montana), and Little Belt (Montana) ranges of the Rocky Mountains were the target areas for the 1989 expedition (Fig. 1). All collection sites were in National Forests except for one site each in Yellowstone and Glacier National Parks. U.S. Forest Service maps were used to locate and identify most sites.

The elevation of collection sites was determined by altimeter and was accurate within $30 \mathrm{~m}$ based on calibrations at reference points where the elevation had been determined by the U.S. Geological Survey. Slope and aspect were determined by planeometer and compass, respectively. Associated flora were noted at each site and used to assign the sites to plant communities described by Daubenmire (1943), Munz and Keck (1959), and Peet (1988).

At each site, seed was collected if available. Where seed was not available, we attempted to collect clonal samples from $\approx 20$ genotypes. Representative herbarium samples were gathered and pressed at most sites. Fruit and clonal specimens were placed in plastic bags and packed in ice chests while in transit. Fruit samples were sent to the $\mathrm{Na}-$ tional Clonal Germplasm Repository (Corvallis) for seed extraction. Clonal material was shipped to the Germplasm Repository, Univ. of Minnesota, or Michigan State Univ. for rooting. Seeds were regenerated from $F$. virginiana clonal material in a greenhouse at Michigan State Univ. in Spring 1990 by random pollination among genotypes collected from within each site. This seed was shared with the Germplasm Repository. Herbarium specimens have been deposited at the Germplasm Repository, North Carolina State Univ., and Michigan State Univ.

On the 1989 expedition, a composite soil sample was collected at each site by taking a 2-cm-diameter core to a depth of $20 \mathrm{~cm}$ adjacent to each collected Fragaria plant. Concentrations of $\mathrm{K}$ (ammonium acetate extractable), P (Bray Pl or Olsen test for soils with $\mathrm{pH}>7.2), \mathrm{pH}[1$ soil : 1 water $(\mathrm{w} / \mathrm{v})]$, and organic matter content (wet digestion) were determined for each sample (Rehm et al., 1985).

\section{DESCRIPTION OF COLLECTIONS}

Collections and site characteristics are summarized in Tables 1 and 2. In the Pacific Northwest, a total of 23 accessions were col- lected from 18 sites including 17 seed samples. Fruits were unripe or unavailable at 41 additional locations where species or species hybrids were observed. The Rocky Mountain collections in 1989 included > 800 clonal specimens and nine seed samples from 45 sites. The individual sites and accessions are described in more detail by Ballington et al. (1988) and Luby and Hancock (1991).

Collection sites included several distinct habitats and were widespread in latitude and altitude. Fragaria virginiana generally occurred in disturbed or open areas such as roadsides or roadbanks, recent clearcuts, gravelly slopes, open woods, and meadows. Several genera that were nearly always associated in the understory of plant communities containing $F$. virginiana were herbaceous Potentilla spp., Berberis aquifolium Pursh, Physocarpus malvaceus (Greene) Kuntz, Holodiscus discolor (Pursh) Maxim., Symphoricarpus oreophilus Gray, Menziesia ferruginea Smith, Ribes spp., Lonicera spp., and Spiraea spp. In the Pacific Northwest, elevations of collection sites ranged from 800 to $2100 \mathrm{~m}$ in Oregon and 400 to $1400 \mathrm{~m}$ in Washington. In the eastern Rocky Mountains, F. virginiana occurred mainly in the spruce-fir [ Picea englemannii Parry - Abies Lasiocarpa (Hook.) Nutt.] and Douglas fir [ Pseudotsuga menziesii (Mirb.) France] zones in sites with moderate moisture and limited competition. Collection from high elevation sites (> $1500 \mathrm{~m}$ ) was emphasized. In western Montana and Idaho, collection sites were often at elevations $<1500$ $\mathrm{m}$ in the drier Ponderosa pine (Pinus ponderosa Dougl.) and Douglas fir zones. Above this elevation, precipitation was high, and tree and shrub growth was so lush that ground cover species such as Fragaria were apparently quickly shaded in openings where they might otherwise have become established.

The diversity of habitats where $F$. virginiana was collected, ranging from dry Pinus ponderosa forests to wet meadows, suggests that valuable traits in certain accessions could include resistance to drought or to conditions associated with saturated soils (anaerobiosis, low nutrient availability, root rot pathogens). Sites having elevation, aspect, soil texture, and soil profile that might contribute to drought or heat stress include LH 4, LH 10, LH 11, LH 22, LH 28, and LH 38 (Table 1). Sites with conditions promoting prolonged soil saturation included BL 27, BL 30, LH 6, LH 29, LH 34, and LH 35 (Table 1). Several collections ( $\mathrm{LH} \mathrm{9,} \mathrm{LH} \mathrm{15,} \mathrm{LH}$ 17, LH 18, LH 45, LH 50) were made near the timberline where the growing season was typically very short (only 6 to 8 weeks, according to local reports) and frost or snow could occur at any time of the year (Table 1). Cold hardiness and blossom frost tolerance may be available from these and other high-altitude sites in the eastern Rocky Mountain ranges.

The sites were quite variable for the soil $\mathrm{pH}$ and content of $\mathrm{K}, \mathrm{P}$, and organic matter (Table 2). Collections from several sites with alkaline soils may be sources of tolerance to higher $\mathrm{pH}$. Soils at sites LH 2 and LH 40 
Table 1. Fragaria collections and site descriptors.

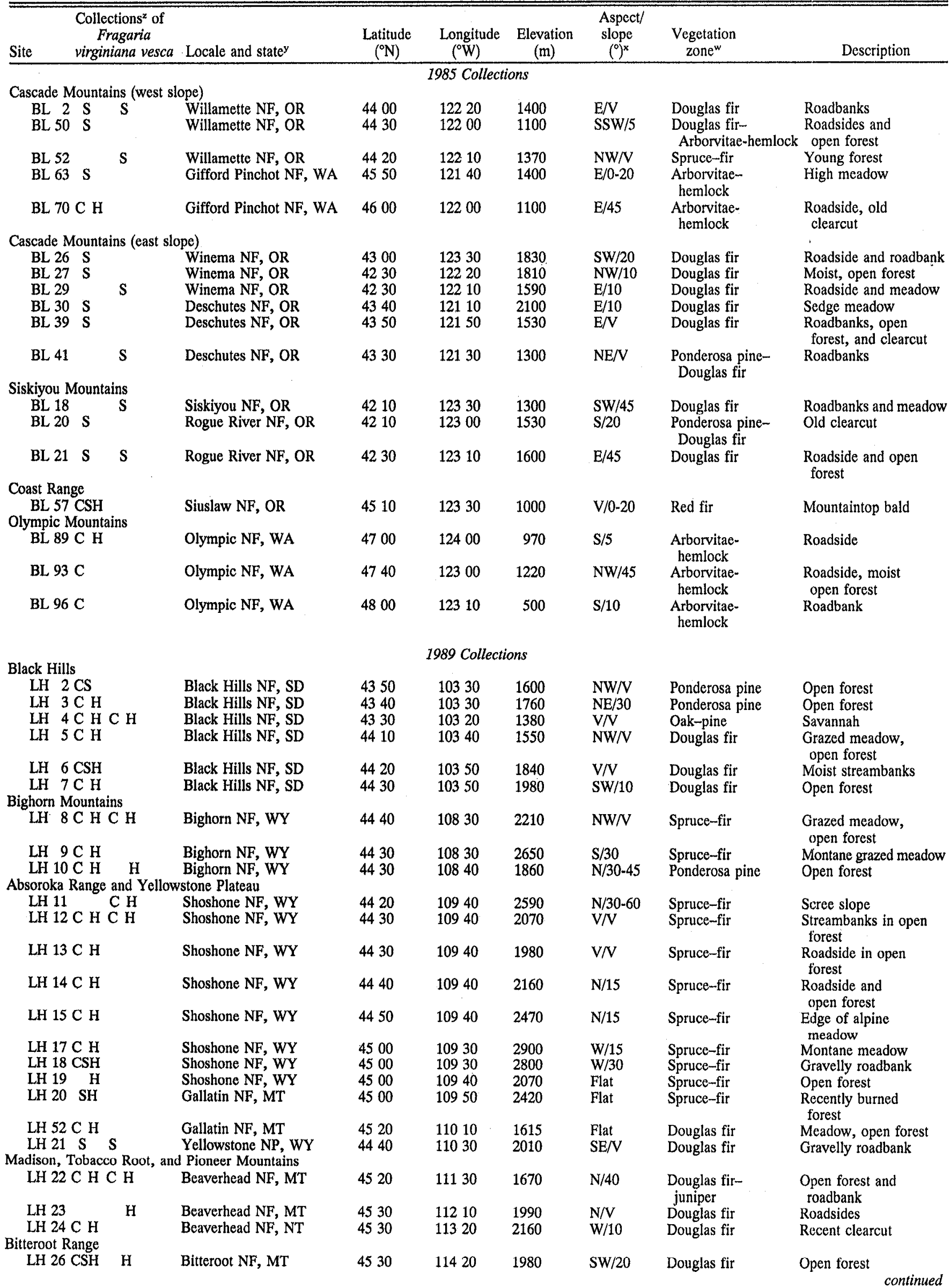




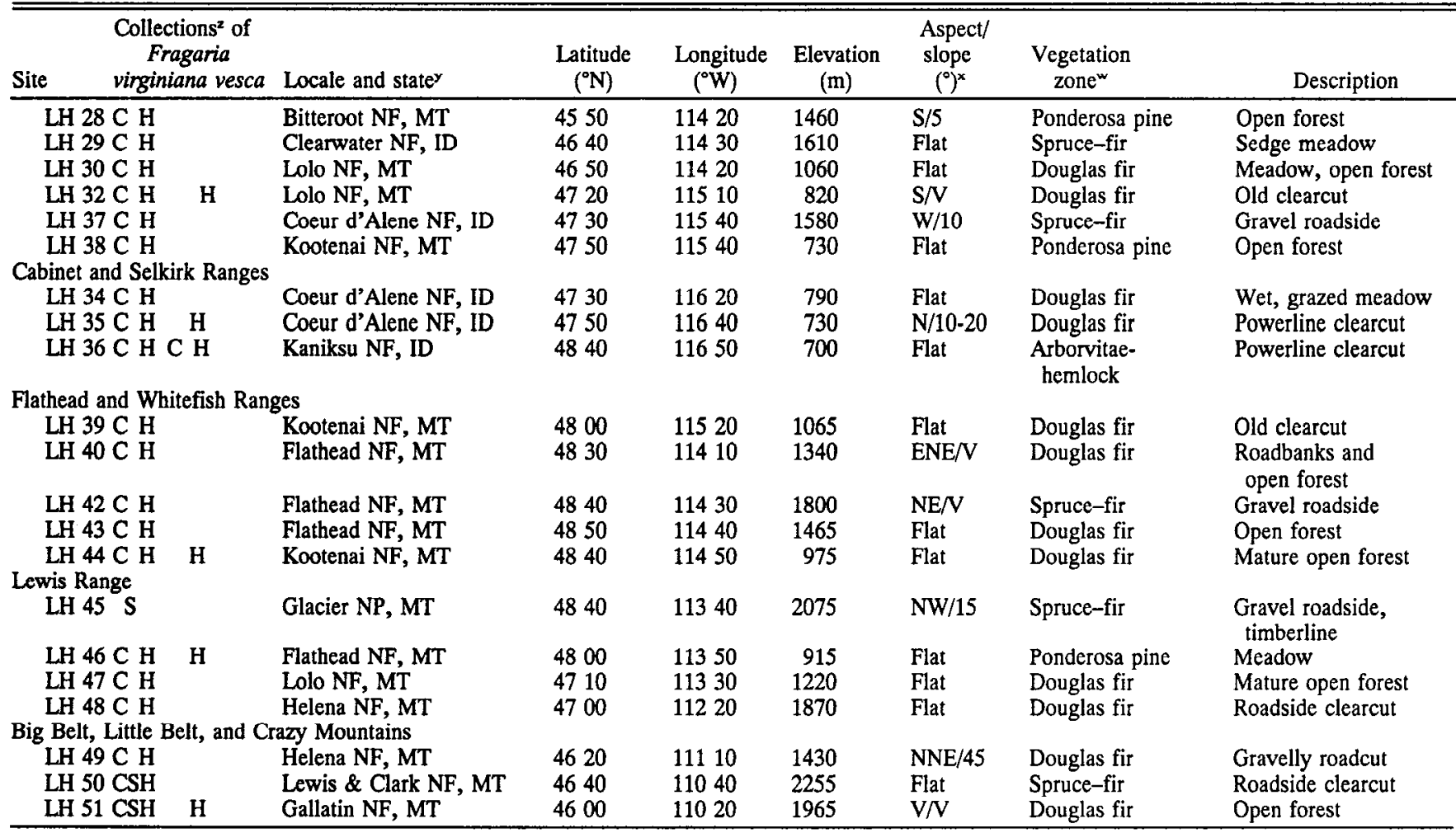

Type of collection from each site: $C=$ clonal (vegetative); $S=$ seed; $H=$ herbarium specimen.

yabbreviations for states are Oregon (OR), Washington (WA), South Dakota (SD), Wyoming (WY), Montana (MT), Idaho (ID).

$\times \mathrm{V}=$ aspect varied or slope varied by more than $30^{\circ}$ over the collection site.

wegetation zones defined by Daubenmire (1943), Munz and Keck (1959), and Peet (1988).

were low in $\mathrm{P}$ and/or $\mathrm{K}$ and these collections may be sources of nutrient-efficient genotypes. The high organic matter content (nearly $10 \%$ ) at some sites was indicative of generally cool, moist conditions that would be conducive to plant growth but might hinder rapid decomposition. Other sites with low organic matter content usually had young soils (e.g., gravel or talus) and tended to be more xeric.

Fragaria virginiana exhibited extensive variability for fruit traits including internal and external color (various shades of pink, orange, and red), flavor, size $(<5$ to $15 \mathrm{~mm}$ diameter), shape, firmness, and degree of seed sunkeness. Several collections, notably BL 2, BL 39, BL 52, LH 18, and LH 51, were especially outstanding for large fruits. We could not accurately determine the gender ratios in most populations because plants did not have flowers or fruits. However, some staminate plants bearing fruit were observed. Day-neutral flowering was observed at sites LH 34, LH 44, LH 45, LH 46, LH 50, and LH 51 and has been observed in the greenhouse on plants from several other sites.

Fragaria vesca was common throughout the collection area. It was often in the same habitats as $F$. virginiana but frequently occupied sites with drier, coarser soils where $F$. virginiana was absent, suggesting that it may be a source of extreme drought tolerance. Fragaria vesca occurred at elevations from 700 to $1600 \mathrm{~m}$ in Oregon and 120 to $1000 \mathrm{~m}$ in Washington. In the Rocky Mountains it was commonly found with $F$. virgi- niana at the lower elevation sites but usually was absent at the high elevation subalpine sites.

\section{SYSTEMATICS OF OCTOPLOID FRAGARIA IN WESTERN NORTH AMERICA}

The mountains of western North America may be a key sampling area for clarification of certain systematic and evolutionary aspects of octoploid Fragaria. Variation patterns in $F$. virginiana have perplexed taxonomists for decades. Rydberg (1922, 1932) assigned species rank to 10 octoploid taxa that would fit within Staudt's (1962) concept of $F$. virginiana in the most recent taxonomic revision of the genus. Staudt himself recognized four subspecies of $F$. virg niana that are regarded as varieties in several recent flora (Hitchcock and Cronquist, 1973; McGregor, 1986; Scoggan, 1978; Weber, 1987; Welsh et al., 1987). Fragaria virginiana ssp. virginiana and ssp. grayana (E. Vilm.) Staudt represent the species in its eastern range with the former being more common in the north (Nova Scotia to Manitoba to Oklahoma to Georgia) and the latter in the south (New York to Alabama, Louisiana and Texas) (Rydberg, 1932; Staudt, 1989).

West of the Great Plains, ssp. glauca (Wats.) Staudt ranges from the southern Rocky Mountains to the parklands of northwest Canada and central Alaska (Staudt, 1989). Fragaria virginiana ssp. platypetala (Rydb.) Staudt is distributed not only through the Rocky Mountains but also in the ranges farther west, from the Sierra Nevada and Cascades to British Columbia (Staudt, 1989) or central Alaska (Hitchcock and Cronquist, 1973). It is distinguished from ssp. glauca by its spreading rather than appressed pubescence on the petiole and scape and by its broader petals and leaflets (Hitchcock and Cronquist, 1973). Welsh et al. (1987) noted, however, that these two forms completely intergrade and suggested that all material be referred to a single taxon, the oldest epithet being var. glauca Wats. Other authors of recent flora of the region apparently adhered to this thinking and recognize only var. glauca (Scoggan, 1978; Weber, 1987) or do not distinguish infraspecific taxa (Dorn, 1977, 1984).

The basis for taxonomic confusion was evident in our collections. Populations in the Black Hills and the eastern front ranges of the Rocky Mountains (e.g., LH 3, LH 7, LH 15, LH 47, LH 50, LH 51, LH 52) appeared to be introgressive swarms between ssp. glauca and ssp. virginiana, supporting the designation of these taxa as varieties rather than subspecies. McGregor (1986) previously noted the phenomenon in this region: "A number of taxa have been isolated from this variable species but intergrade rather completely. They are not at all clearly delimitable in our area."

In the late Pleistocene, the Great Plains region of North America was mainly boreal forest (Kaul, 1986). This plant community would have provided a continuous habitat across the continent for Fragaria and, there- 
Table 2. Soil characteristics (0 to $0.15-\mathrm{m}$ depth) from Fragaria virginiana collection sites in the northern Rocky Mountains.

\begin{tabular}{|c|c|c|c|c|c|}
\hline Site & $\underset{\left(\mathrm{mg} \cdot \mathrm{kg}^{-1}\right)}{\mathrm{P}}$ & $\underset{\left(\mathrm{mg} \cdot \mathrm{kg}^{-1}\right)}{\mathrm{K}}$ & $\mathrm{pH}$ & $\begin{array}{l}\text { Organic } \\
\text { matter } \\
(\%)\end{array}$ & Description $^{2}$ \\
\hline LH2 & $5^{y}$ & 67 & 7.9 & 3.0 & Sandy and gravelly \\
\hline LH3 & 32 & 133 & 6.7 & 4.8 & Gravelly (granite, quartzite) \\
\hline LH4 & 31 & 164 & 6.6 & 6.3 & Clay and silt \\
\hline LH5 & 21 & 191 & 6.8 & 6.7 & Thin clay layer over shale \\
\hline LH6 & 18 & 206 & 7.6 & 9.9 & $\begin{array}{l}10-15 \mathrm{~cm} \text { of clay with bigh organic } \\
\text { matter, some gravel }\end{array}$ \\
\hline LH7 & 23 & 167 & 6.3 & 8.2 & No comments \\
\hline LH8 & 54 & 197 & 5.8 & 7.5 & Loose humus \\
\hline LH9 & 75 & 279 & 5.6 & 7.2 & Deep loam \\
\hline LH10 & 13 & 248 & 7.2 & 7.2 & Gravelly humus \\
\hline LH11 & 50 & 256 & 6.3 & 4.7 & Silty, thick humus \\
\hline LH12 & 51 & 133 & 6.6 & 5.3 & No comments \\
\hline LH13 & 54 & 420 & 6.5 & 6.1 & Deep, moist, heavy texture \\
\hline LH14 & 15 & 91 & 7.8 & 6.0 & No comments \\
\hline LH15 & 8 & 111 & 7.9 & 6.1 & $\begin{array}{l}\text { High organic matter with } \\
\text { weathered gypsum }\end{array}$ \\
\hline LH17 & 17 & 194 & 6.5 & 4.6 & Deep, high organic matter \\
\hline LH22 & 12 & 187 & 7.6 & 4.6 & Deep, gravelly \\
\hline LH24 & 71 & 157 & 5.4 & 4.3 & Silty \\
\hline LH26 & 28 & 145 & 5.9 & 4.1 & $10-15 \mathrm{~cm}$ light soil over rock \\
\hline LH28 & 58 & 142 & 5.2 & 6.1 & Thin organic layer over rock \\
\hline LH29 & 17 & 164 & 5.4 & 7.5 & Highly organic \\
\hline LH30 & 28 & 115 & 6.3 & 7.7 & No comments \\
\hline LH32 & 53 & 167 & 6.5 & 5.2 & No comments \\
\hline LH34 & 24 & 140 & 5.9 & 7.1 & High clay and organic matter \\
\hline LH35 & 64 & 203 & 6.6 & 6.0 & Deep, moist, red clay \\
\hline LH36 & 46 & 93 & 6.7 & 3.2 & Deep, red loamy sand \\
\hline LH38 & 136 & 404 & 6.4 & 3.5 & Gravelly \\
\hline LH39 & 180 & 149 & 6.1 & 2.2 & Deep, very dry \\
\hline LH40 & $3^{y}$ & 64 & 7.7 & 2.5 & No comments \\
\hline LH43 & 81 & 110 & 6.1 & 5.3 & No comments \\
\hline LH44 & 60 & 136 & 6.0 & 2.9 & No comments \\
\hline LH46 & 97 & 112 & 6.1 & 6.1 & Gravelly, alluvial \\
\hline LH47 & 100 & 98 & 5.5 & 4.3 & Deep sandy loam \\
\hline LH48 & 69 & 139 & 6.4 & 5.0 & Clay with gravel \\
\hline LH49 & $4^{y}$ & 162 & 8.0 & 3.2 & Shale chips and clay \\
\hline LH50 & 25 & 125 & 6.4 & 3.8 & No comments \\
\hline LII51 & 56 & 228 & 6.0 & 8.4 & No comments \\
\hline LH52 & 13 & 157 & 6.9 & 4.2 & No comments \\
\hline
\end{tabular}

${ }^{2}$ Comments recorded at the collection site.

y Olsen $\mathrm{P}$ value presented where the Olsen value exceeded the Bray value at sites with $\mathrm{pH}>7.2$.

fore, extensive opportunity for gene flow between eastern and western populations as they spread north with the retreating ice sheet and coalesced (Staudt, 1989). Hybridization and introgression may have occurred between $F$. virginiana ssp. glauca and eastern $F$. virginiana ssp. virginiana in the Black Hills and eastern Rocky Mountains. When the plains later became hotter and drier, these populations were left as Ice Age relics in which the characters that distinguish the two contemporary taxa have not become uniformly intermediate or lost due to selective pressure. We were unable to find populations in central South Dakota or central or western North Dakota that might provide a link between the two subspecies. However, sampling was quite limited and further exploration in the area is critical.

The western exploration areas were equally interesting from an evolutionary standpoint. The distributions and habitats of $F$. virginiana and $F$. chiloensis are geographically close in the Pacific Northwest (Hitchcock and Cronquist, 1973). Putative hybrids between $F$. virginiana and $F$. chiloensis were noted at four sites (BL 57, BL 70, BL 89, BL 93) in the Coast Range, the western Cascades, and the Olympic Mountains. Populations in western Montana and Idaho (LH 29, LH 34, LH 35, LH 37, LH 47) also had a combination of characters reminiscent of $F$. chiloensis - thick runners, thick, rounded leaves, and red petioles. These plants were similar to the woods-meadow populations of F. chiloensis described by Hancock and Bringhurst (1979) as having characters of $F$. virginiana. They are also similar to plants described by Staudt (1962) from Vancouver Island and Washington, and by Scoggan (1978) from southwest Alberta assigned to $F$. ananassa nm. cuneifolia (Nutt. ex. Howell) Staudt as putative hybrid derivatives of $F$. chiloensis and $F$. virginiana. Staudt (1989) noted that "hybrid populations of $F$. chiloensis $x F$. virginiana still exist from Vancouver Island along the coast south to Ft. Bragg, California" and that "the further one goes from the coastal area the more the $F$. chiloensis characteristics decrease, Plants with somewhat thinner leaves but some other characteristics of $F$. chiloensis are combined in ssp. platypetala of $F$. virginiana... considered to be the final link of an introgression of $F$. chil- oensis into $F$. virginiana ssp. glauca."

The timing and extent of possible gene flow between the species are intriguing questions as the Montana and Idaho sites are nearly $1000 \mathrm{~km}$ from the coastal habitat of $F$. chiloensis. Introgression from the cultivated strawberry could have occurred, although many of our collection sites were isolated from human settlements. Staudt (1989) speculated that hybidization probably occurred after glaciation in the Fraser River valley of British Columbia. Another possibility is that $F$. chiloensis and $F$. virginiana ssp. glauca are alternative forms of a single biological species, separated during the Pleistocene, and altered by selection for adaptation to coastal or montane, continental habitats. This change would be consistent with an origin for octoploid strawberries in east Asia and dispersal along the northern Pacific islands, through Alaska, and south throughout North America. Indeed, $F$. iturupensis of the western Pacific has glaucous leaves like $F$. virginiana ssp. glauca (Staudt, 1973). In South America, Fragaria chiloensis ranges through the habitats that contain $F$. chiloensis and $F$. virginiana ssp. glauca in North Americafrom Pacific Ocean beaches and headlands to montane forests at $1900 \mathrm{~m}$ elevation (Bringhurst et al., 1989; Cameron et al., 1991; Darrow, 1966). At high elevations in Chile, plants also have the glaucous, thin leaves characteristic of $F$. virginiana ssp. glauca (Bringhurst et al., 1989). Bringhurst et al. (1989) note that the glossy-leaved $F$. chiloensis characteristic of the coastal fog belt in California is rare in Chile and that most of the Chilean material more nearly resembles the North American types that derived from putative hybridization of $F$. chiloensis with $F$. virginiana (Hancock and Bringhurst, 1979).

In addition to collections that suggested gene exchange among octoploid taxa, $F$. virginiana plants at one location (BL 63) had characteristics of the diploid $F$. vesca including very erect, long peduncles and nonsunken achenes. These plants (of unknown ploidy) may be derivatives of interploid hy bridization similar to the natural pentaploid hybrids between $F$. chiloensis and $F$. vesca described from several Pacific coast sites in California (Bringhurst, 1990; Bringhurst and Senanayake, 1966).

These various introgressed populations could yield horticulturally interesting combinations of genes from divergent types. $\mathrm{Nu}$ merical and biochemical taxonomic characterization and further intense collection from these geographic areas may clarify the evolutionary and taxonomic relationships. Evaluation of recent Chilean collections (Cameron et al., 1991) and future collections in Alaska, the northern and western Pacific islands, and the east Asian mainland will be critical in furthering the understanding of Fragaria speciation at the octoploid level, (Staudt, 1989).

\section{Literature Cited}

Ahmadi, H., R.S. Bringhurst, and V. Voth. 1990 Modes of inheritance of photoperiodism in $\mathrm{Fra}$ - 
garia. J. Amer. Sot. Hort. Sci. 115:146-152.

Ballington, J.R., J.J. Luby, and O.L. Jahn. 1988. Small fruit germplasm collections in Pacific Northwest, July 21 through August 13, 1985. North Carolina State Univ. Hort. Crops Res. Ser. No. 78.

Bringhurst, R.S. 1990. Cytogenetics and evolution in American Fragaria. HortScience 25:879881.

Bringhurst, R.S., H. Ahmadi, and V. Voth. 1989. Genetic regulation of fruiting; p. 307-314. In: C.J. Wright (ed.). Manipulation of fruiting Butterworths, London.

Bringhurst, R.S. and V. Voth. 1984. Breeding octoploid strawberries. Iowa State J. Res. 58:371-381

Bringhurst, R.S., J.F. Hancock, and V. Voth. 1977. The beach strawberry. an important natural resource. Calif. Agr. 31:10.

Bringhurst, R.S. and Y.D.A. Senanayake. 1966 The evolutionary significance of natural Fragaria chiloensis $\mathrm{x} F$. vesca hybrids resulting from unreduced gametes. Amer. J. Bot. 53:1000-1006.

Cameron, J.S., T.M. Sjulin, C.H. Shanks, Jr., and C.E. Munoz. 1991. Collection of Fragaria chiloensis in central and southern Chile, p. 108 110. In: A. Dale and J. Luby (eds.). The strawberry into the 21 st century. Timber Press, Portland, Ore.

Dale, A. and T.M. Sjulin. 1990. Few cytoplasms contribute to North American strawberry cultivars. HortScience 25:1341-1342.

Darrow, G.M. 1966. The strawberry: history, breeding and physiology. Holt, Rinehart and Winston, New York.

Daubenmire, R.M. 1943. Vegetational zonation in the Rocky Mountains. Bot. Rev. 9:325-393.

Dom, R.D. 1977. Manual of the vascular plants of Wyoming. Garland Pub. Co., New York.

Dom, R.D. 1984. Vascular plants of Montana. Mountain West Pub., Cheyenne, Wyo.

Galletta, G.J. and J.L. Maas. 1990. Strawberry genetics. HortScience 25:871-879.

Hancock, J.F. 1977. Ecogenetics of California species of Fragaria: Habitats, morphology, enzymes and physiological tolerances of octoploids $F$. chiloensis and $F$. virginiana, and diploid $F$. vesca. PhD. Diss., Univ. of California, Davis.

Hancock, J.F. and R.S. Bringhurst. 1978. Interpopulation differentiation and adaptation in the perennial, diploid species Fragaria vesca L. Amer. J. Bot. 65:795-803.

Hancock, J.F. and R.S. Bringhurst. 1979. Ecological differentiation in perennial, octoploid species of Fragaria Amer. J. Bot. 66:367-375

Hancock, J.F. and R.S. Bringhurst. 1988. Yield component interactions in wild populations of California Fragaria. HortScience 23:889-891.

Hancock, J.F., J.L. Maas, C.H. Shanks, P.J. Breen, and J.J. Luby. 1990. Strawberries (Fragaria ssp.), p. 489-546. In: J.N. Moore and J.R. Ballington (eds.). Genetic resources in temperate fruit and nut crops. Intl. Sot. Hort. Sci. Wageningen, Netherlands.

Hildreth, A.C. and L. Powers. 1941. The Rocky Mountain strawberry as a source of hardiness. Proc. Amer. Sot. Hort. Sci. 38:410-412.

Hitchcock, C.L. and A. Cronquist. 1973. Flora of the Pacific Northwest. Univ. of Washington Press, Seattle.

Kaul, R.B. 1986. Physical and floristic characteristics of the Great Plains. Great Plains Flora Association, flora of the Great Plains. University Press of Kansas, Lawrence.

Luby, J.J. and J.F. Hancock. 1991. Collection of Fragaria and other small fruit genera in the northern Rocky Mountains U.S.A. Michigan State Univ. Res. Rpt. 511.
Luby, J.J., J.F. Hancock, and J.S. Cameron. 1991. Expansion of the strawberry germplasm base in North America, p. 66-75. In: A. Dale and J. Luby (eds.). The strawberry into the 21 st century. Timber Press, Portland, Ore.

McGregor, R.L. 1986. Rosaceae. Great Plains Flora Association, flora of the Great Plains. University Press of Kansas, Lawrence.

Munz, P.A. and D.D. Keck. 1959. A California flora. Univ. of California Press, Berkeley.

Newton, W. and M.C.J. Van Adrichem. 1958 Resistance to verticillium wilt in $\mathrm{F}_{1}$ generations of Fragaria. Can. J. Bot. 36:297-299.

Oda, Y. and S. Nisitani. 1989. Chromosome numbers of strawberries native to Japan. Chromosome Info. Serv. 47:26-27.

Ourecky, D.K. and G.L. Slate. 1968. Behavior of everbearing characteristics in strawberries. Proc. Amer. Sot. Hort. Sci. 91:236-241.

Peet, R.K. 1988. Forests of the Rocky Mountains, p. 63-103. In M.G. Barbour and W.D. Billings (eds.). North American terrestrial vegetation. Cambridge Univ. Press, Cambridge, England.

Powers, L. 1944. Meiotic studies of crosses between Fragaria ovalis and $F . \times$ ananassa. J. Agr. Res. 69:435448.

Powers, L. 1945. Strawberry breeding studies involving crosses between the cultivated varieties Fragaria $\times$ ananassa and the native Rocky Mountain strawberry $F$. ovalis. J. Agr. Res. 70:95-122.

Powers, L. 1954. Inheritance of period of blooming in progenies of strawberries. Proc. Amer. Sot. Hort. Sci. 64:293-298.

Rehm, G.W., C.J. Rosen, J.F. Moncrief, W.E. Fenster, and J. Grava. 1985. Guide to computer programmed soil test recommendations. Agr. Expt. Ser. AG-BU-0519. Univ. of Minnesota, St. Paul.

Rydberg, P.A. 1922. Flora of the Rocky Mountains and adjacent plains. New York Botanical Garden, New York.

Rydberg, P.A. 1932. Flora of the prairies and plains of central North America. New York Botanical Garden, New York.

Scoggan, H.J. 1978. The flora of Canada. National Museums of Canada, Ottawa.

Scott, D.H. 1959. Size, firmness, and time of ripening of fruit of seedlings of Fragaria virginiana Duch. crossed with cultivated strawberry varieties. Proc. Amer. Sot. Hort. Sci. 74:388393

Scott, D.H. and F.J. Lawrence. 1975. Strawberries, p. 71-97. In: J. Janick and J.N. Moore (eds.). Advances in fruit breeding. Purdue Univ. Press, West Lafayette, Ind.

Sjulin, T.M. and A. Dale. 1987. Genetic diversity of North American strawberry cultivars. J. Amer. Sot. Hort. Sci. 112:375-385.

Staudt, G. 1962. Taxonomic studies the genus Fragaria. Typification of species known at the time of Linnaeus. Can. J. Bot. 40:869-886.

Staudt, G. 1973. Fragaria iturupensis, eine neue Erdbeerart aus Ostasien. Willdenowia 7:101104.

Staudt, G. 1989. The species of Fragaria, their taxonomy and geographical distribution. Acta Hort. 265:23-33.

Welsh, S.L., N.D. Atwood, S. Goodrich, and L.C. Higgins. 1987. A Utah flora. Great Basin Naturalist Memoirs, no. 9. Brigham Young Univ., Provo, Utah. 